\title{
Growth rates and yields of cassava at different planting dates in a tropical savanna
}

\section{climate}

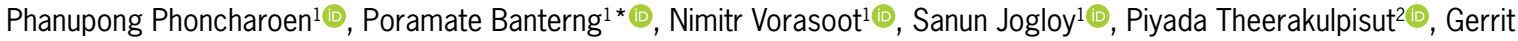 \\ Hoogenboom ${ }^{3}$
}

\author{
${ }^{1}$ Khon Kaen University/Faculty of Agriculture - 40002 - Khon \\ Kaen - Thailand. \\ ${ }^{2}$ Khon Kaen University/Faculty of Science. \\ 3University of Florida/Institute for Sustainable Food Systems, \\ Agricultural and Biological Engineering Dept., 184 Frazier \\ Rogers Hall - 32611-0570 - Gainesville, FL - USA. \\ *Corresponding author <bporam@kku.ac.th>
}

Edited by: Axel Garcia y Garcia

Received December 12, 2017

Accepted May 08, 2018
ABSTRACT: Details on growth and yield for cassava planted on different dates are useful for determining suitable genotypes for particular growing seasons. Our aim was to study growth and yield of cassava planted on different dates. Four cassava genotypes (Kasetsart 50, Rayong 9, Rayong 11 and CMR38-125-77) were evaluated using a randomized complete block design (RCBD) with four replications in six growing periods (20 Apr, 25 May, 30 June, 5 Oct, 10 Nov and 15 Dec 2015-2016) at Khon Kaen, Thailand. Soil properties were determined prior to planting, and crop traits and weather data were recorded. The six planting dates had a statistically significant effect on all crop traits. Low temperatures and solar radiation related to low biomass accumulation rates and short periods of linear phases for total crop and storage root dry weights with the 30 June planting date. CMR38-125-77 is likely to be a good genotype with respect to total crop and storage root dry weights at final harvest for almost all growing dates, except for the 20 Apr. Leaf area index (LAl) at 120, 240 and 300 days after planting (DAP), specific leaf area (SLA) at 120 DAP, storage root growth rate (SRGR) during 300-360 DAP and leaf growth rate (LGR) during 60-120 and 300-360 DAP were the components for the physiological determinants of total crop and storage root dry weight. The relationship between these physiological traits and storage root could be useful for cassava breeding.

Keywords: climatic factors, environment, growth analysis, growing date

\section{Introduction}

Cassava (Manihot esculenta Crantz) is normally grown in tropical and subtropical regions (Howeler, 2014). Thailand is one of the world's major cassava producers. However, the average cassava yield in the country is still lower than expected levels. The potential simulated and obtained experimental cassava yields under favorable conditions vary from 25 to $30 \mathrm{t} \mathrm{ha}^{-1}$ of dry weight (approximate 80 to $90 \mathrm{t} \mathrm{ha}^{-1}$ fresh weight) (Cock et al., 1979; El-Sharkawy et al., 1990; El-Sharkawy, 1993). The majority of the cassava growing areas in Thailand are in the tropical savanna climate zone, and the growing period covers almost all seasons (Thailand Ministry of Agriculture and Cooperatives, 2008). To increase cassava productivity, the most effective option is to choose the appropriate genotype for cultivation with suitable planting dates and supplementary irrigation. Variability in crop responses to diverse weather conditions with different planting dates is a normal occurrence in cassava. Temperature and solar radiation affected crop growth rate, leaf area index, (LAI) specific leaf area (SLA) and yield (Irikura et al., 1979; Keating et al., 1982a, b; Fukai et al., 1984a, b; Aye, 2012).

Since inconsistency in cassava performance with different planting dates has been a common occurrence, selecting cassava genotypes with high productivity for various growing dates is a challenging task for plant breeders. Furthermore, the International Center for Tropical Agriculture (CIAT), Colombia, adopted a breeding strategy based on selection for specific agroecozones with different edaphic and climatic conditions (Jennings and Iglesias, 2002). Breeders generally select the desirable genotypes based on yield and harvest index (HI) (Kawano, 1990; Banterng et al., 2006). However, final crop yield is the result of crop growth rates and underlying physiological changes (Boote et al., 2001). A study of the physiological traits such as growth rate of crop (CGR), stem (SGR), leaf (LGR) and storage root (SRGR), as well as LAI and SLA of different cassava genotypes responsible for different yield performances in various planting dates could provide more information concerning the influence of climatic factors on growth habit and yield. Research at CIAT, emphasized the relationship between photosynthetic capacity of leaves and crop productivity as a selection trait in breeding (El-Sharkawy et al., 1990; El-Sharkawy, 2006). Additional knowledge of cassava growth analysis and physiological determinants of yield with different planting dates should be explored. The aim of this research was to investigate growth and yield of different cassava genotypes planted on different growing dates.

\section{Materials and Methods}

\section{Experimental information}

Four different cassava branching genotypes were used in this study. Kasetsart 50 genotype (branching type) was introduced in Thailand in 1993. Rayong 9 (non-branching type) and Rayong 11 (branching type) were released in Thailand in 2005 and 2010, respective- 
ly. CMR38-125-77 (branching type) was the elite genotype. Performances of the four cassava genotypes were evaluated at Khon Kaen, Thailand $\left(16^{\circ} 28^{\prime} 27^{\prime \prime} \mathrm{N}\right.$ and $102^{\circ} 48^{\prime} 36^{\prime \prime}$ E, $195 \mathrm{~m}$ a.l.s.) during 2015-2016 by using a randomized complete block design (RCBD) with four replications. Plot size and plant spacing for each cassava stake were $196 \mathrm{~m}^{2}$ and $1 \times 1 \mathrm{~m}$, respectively.

Land preparation was carried out by following the normal procedures for experimental fields of cassava. The stems of cassava at nine months after planting were cut as stakes $20 \mathrm{~cm}$ in length soaked with thiamethoxam $25 \%$ water dispersible granules (WG) at a rate of 4 g per 20 liters of water for $30 \mathrm{~min}$ to protect against the cassava mealy bug (Thailand Ministry of Agriculture and Cooperatives, 2008). The cassava stakes of four different cassava genotypes were then planted vertically on the ridges during 2015-2016 in order to evaluate the six different planting dates (20 Apr, 25 May, 30 June, 5 Oct, 10 Nov and 15 Dec 2015). Weeds were manually controlled throughout the experimental fields. At one month after planting, $\mathrm{KCl}$ fertiliser was applied based on soil properties that were determined before planting and information from Howeler (2002). Additionally, (NH) $\mathrm{SO}_{4}$ fertiliser was applied at a rate of $46.9 \mathrm{~kg} \mathrm{ha}{ }^{-1}$. N-P $\mathrm{P}_{2} \mathrm{O}_{5}-\mathrm{K}_{2} \mathrm{O}$ formula 15-0-18 was applied at the rate of $312.5 \mathrm{~kg} \mathrm{ha}^{-1}$ two months after planting (Thailand Ministry of Agriculture and Cooperatives, 2008). Soil moisture content in the experimental fields was determined using sets of tensiometers placed at depths of $20 \mathrm{~cm}$ and $40 \mathrm{~cm}$ for all six planting dates. When water tension at $40 \mathrm{~cm}$ of soil depth was below $-30 \mathrm{kPa}$, supplementary irrigation was applied with an overhead sprinkler system in order to avoid crop water stress situations; irrigation was terminated when the water tension at this depth was between -20 and $-10 \mathrm{kPa}$.

\section{Data collection}

For each planting date, soil samples prior to planting were taken from four points at depths of up to 30 $\mathrm{cm}$. The following chemical and physical proprieties were determined: percentage of sand, silt and clay, soil $\mathrm{pH}$, cation exchange capacity, organic matter, total nitro- gen, available phosphorus and exchangeable potassium. The soil textures were sandy with low total nitrogen and organic matter contents. Other physical and chemical characteristics of the soil prior to planting (shown in Table 1) indicated poor soil fertility. However, the results indicated high amounts of available phosphorus with sufficient concentration to meet the cassava requirement as proposed by Howeler (2002). Therefore, phosphorus fertiliser was not applied in the experimental fields.

Six plants from each experimental plot were sampled at $60,120,180,240,300$ and 360 days after planting (DAP) for all six planting dates to determine growth rates, LAI and SLA. In addition, 18 plants per plot were sampled to determine final yield, starch content and HI at 360 DAP. The sampled plants were separated into individual organs, such as leaves, petiole, stem, root and storage root. All plant materials were then subsampled (about $10 \%$ of the total fresh weight of each organ). Subsamples of green leaves were used to measure leaf area using a leaf area meter. Subsamples of all plant organs were oven-dried at $80^{\circ} \mathrm{C}$ until constant weight was achieved, to determine the dry weight of the individual plant organs. Growth rates (CGR, LGR, SGR and SRGR) for three different crop durations ((1) canopy and root development and storage root bulking: 60-120 DAP, (2) high carbohydrate partitioning to storage root: 180-240 DAP, and (3) declining phase: 300-360 DAP (Alves, 2002)) were calculated for each plant organ as the change in dry weight per ground area per unit of time. The total leaf area of the subsample and its corresponding dry weight at 120, 240 and 300 DAP were then used to calculate SLA. The LAI values at 120, 240 and 300 DAP were calculated as the ratio of canopy leaf area to ground area. The HI values at 360 DAP were calculated as the ratio of storage root dry weight to total crop dry weight (Banterng et al., 2003; Koutroubas et al., 2009). In addition, daily maximum and minimum temperatures, amount of solar radiation and rainfall were recorded by an automatic weather station.

\section{Statistical analysis}

Analysis of variance (ANOVA) for each individual planting date, combined analysis for all six planting

Table 1 - Soil properties prior to planting at the depth of 0-30 $\mathrm{cm}$ for six different planting dates.

\begin{tabular}{|c|c|c|c|c|c|c|}
\hline \multirow{2}{*}{ Soil property } & \multicolumn{6}{|c|}{ Planting date } \\
\hline & $20 \mathrm{Apr}$ & 25 May & 30 June & 5 Oct & $10 \mathrm{Nov}$ & $15 \mathrm{Dec}$ \\
\hline \multicolumn{7}{|l|}{ Physical property } \\
\hline Sand (\%) & 81.96 & 80.82 & 78.51 & 74.19 & 81.89 & 79.76 \\
\hline Silt (\%) & 11.37 & 10.09 & 7.20 & 11.75 & 9.72 & 11.62 \\
\hline Clay (\%) & 6.68 & 9.09 & 14.29 & 14.06 & 8.40 & 8.61 \\
\hline \multicolumn{7}{|l|}{ Chemical property } \\
\hline $\mathrm{pH}$ & 7.30 & 6.27 & 5.04 & 5.29 & 5.64 & 5.39 \\
\hline Cation exchange capacity (cmol kg-1) & 6.62 & 7.80 & 3.52 & 4.60 & 6.38 & 6.99 \\
\hline Organic matter (g kg-1) & 3.7 & 3.1 & 2.9 & 4.8 & 3.1 & 2.7 \\
\hline Total nitrogen $\left(\mathrm{g} \mathrm{kg}^{-1}\right.$ ) & 0.2 & 0.2 & 0.1 & 0.2 & 0.1 & 0.1 \\
\hline Available phosphorus (mg kg-1) & 56.85 & 45.02 & 9.89 & 16.10 & 32.60 & 15.45 \\
\hline Exchangeable potassium (mg kg-1) & 27.63 & 27.70 & 17.86 & 36.42 & 52.31 & 21.82 \\
\hline
\end{tabular}


dates and mean comparisons based on the least significant difference test (LSD) were performed on all crop growth data. Multiple regression analysis was used to examine the relationship between physiological traits (CGR, LGR, SGR and SRGR, LAI and SLA) and final dry weights of the crop, as well as storage root yield. The ANOVA and mean comparisons were conducted using MSTAT-C version 1.42 program. The logistic function and regression analysis were completed using SigmaPlot, version 10.0.

\section{Results}

\section{Weather conditions and logistic curves for six different growing dates}

During the period from Apr 2015 to Dec 2016 (Figure 1 ), daily mean temperature, maximum temperature, minimum temperature and solar radiation for the hot season (mid-Feb to mid-May) ranged from $22.5-35.6{ }^{\circ} \mathrm{C}$, 29.2-43.9 ${ }^{\circ} \mathrm{C}$, $14.3-29.5^{\circ} \mathrm{C}$ and 7.2-23.4 $\mathrm{MJ} \mathrm{m}^{-2} \mathrm{~d}^{-1}$, respectively; for the rainy season (mid-May to mid-Oct) ranges were from 22.6-33.4 ${ }^{\circ} \mathrm{C}, 24.2-40.1{ }^{\circ} \mathrm{C}, 20.8-28.3$ ${ }^{\circ} \mathrm{C}$ and 4.6-25.4 $\mathrm{MJ} \mathrm{m}^{-2} \mathrm{~d}^{-1}$, respectively; and for the cool season (mid-Oct to mid-Feb) ranges varied from 12.329.2 ${ }^{\circ} \mathrm{C}, 16.8-38.7{ }^{\circ} \mathrm{C}, 8.9-24.7^{\circ} \mathrm{C}$ and 5.4-24.5 $\mathrm{MJ} \mathrm{m}^{-2}$ $\mathrm{d}^{-1}$, respectively. The total amount of rainfall in that period was $1,888.4 \mathrm{~mm}$. Although there were differences in rainfall for the six growing dates, supplementary irrigation was also applied during dry periods, which were identified using sets of tensiometers placed at soil depths of $20 \mathrm{~cm}$ and $40 \mathrm{~cm}$. Thus, rainfall might not have been a limiting factor for the cassava crop grown on the six different planting dates.

Based on the logistic curves for total biomass accumulation (Figure 2A and B), the exponential phases of cassava were carried out during the hot and rainy seasons for the 20 Apr planting date, the rainy season for the 25 May and 30 June planting dates, and the cool season for the 5 Oct, 10 Nov and 15 Dec planting dates. According to the linear phase, cassava experienced the rainy season to the cool season for the 20 Apr, 25 May and

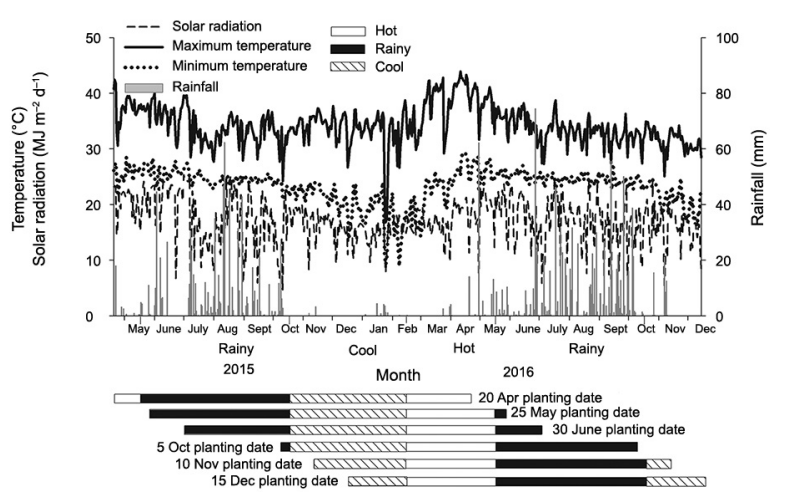

Figure 1 - Maximum temperature, minimum temperature, solar radiation and rainfall during 2015 to 2016 at Khon Kaen, Thailand.
30 June planting dates and the hot season to the rainy season for the 5 Oct, 10 Nov and 15 Dec planting dates. The linear phases of the logistic curves for total biomass for each planting date were also determined through different season durations. The 5 Oct, 10 Nov and 15 Dec planting dates had a lower rate of total biomass accumulation during the exponential phase compared to the other three planting dates. The planting dates of 20 Apr and 10 Nov had more total biomass accumulation with longer periods of high production rate in the linear phase or grand period of growth compared to the other planting dates. Similar results were reported for storage root accumulation (data not shown).

According to the weather conditions during the three different crop durations, low temperatures during 60-120 DAP for the 5 Oct, 10 Nov and 15 Dec planting dates (cool season) (Table 2) slightly expanded the exponential phase for total biomass (Figure 2B). During

A

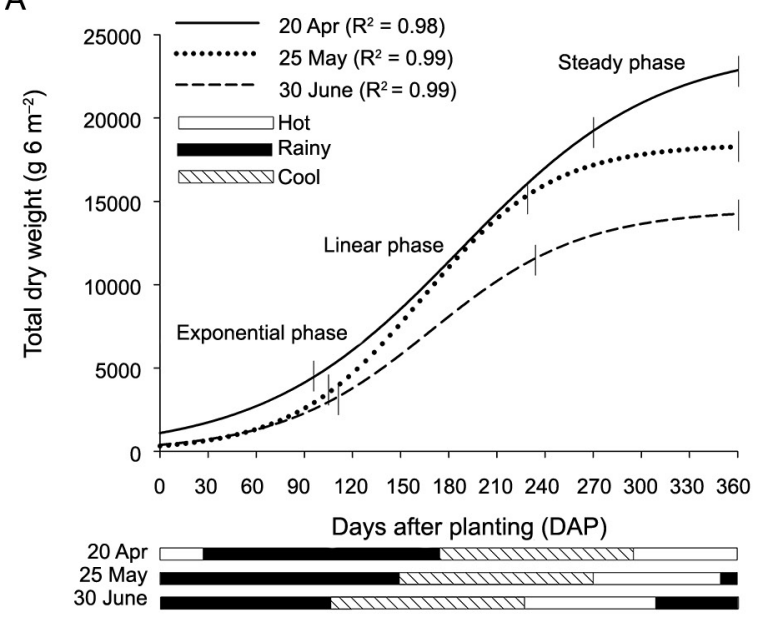

B

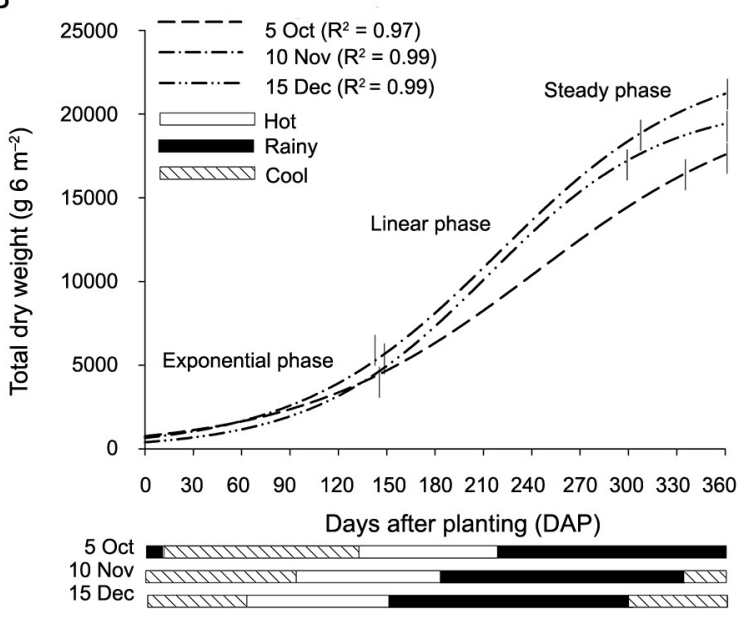

Figure 2 - Total dry weight patterns of cassava grown on $20 \mathrm{Apr}$, 25 May and 30 June planting dates (A) and 5 Oct, 10 Nov and 15 Dec planting dates (B). 
the 180-240 DAP for the 25 May and 30 June planting dates (cool season), low temperatures and solar radiation (Table 2) decreased the period of the linear phase and reduced the rate of total biomass accumulation (30 June plating date) (Figure 2A). The results for the growth of the storage root were similar (data not shown), except during the 180-240 DAP for the 25 May and 30 June planting dates which had high storage root growth rates. However, the short period of these high growth rates ultimately caused low storage root production.

\section{Performances of four cassava genotypes for each planting date}

The results of analysis of variance for each individual planting date (Figure 3A) showed that CMR38125-77 had the highest values of total dry weight, with statistical significances for the 30 June $(p<0.05)$ and 15 Dec planting dates $(p<0.05)$, and Rayong 9 for the 5 Oct planting date $(p<0.05)$. Although Kasetsart 50 did not have the highest ranking in terms of total dry weight, it could be identified as a top genotype for the 30 June, 5 Oct and 15 Dec planting dates. The logistic curves in Figure 4A, B, C, D, E and F indicated that CMR38-125-77 demonstrated good performance based on total dry weight accumulation for almost all planting dates, with the exception of the 20 Apr planting date. Kasetsart 50 had high total dry weight accumulation for the 20 Apr, 25 May, 10 Nov and 15 Dec planting dates. There were significant differences between the four cassava genotypes $(p<0.05)$ for most planting dates in terms of storage root fresh weight (except for the 25 May planting date), and storage root dry weight also had

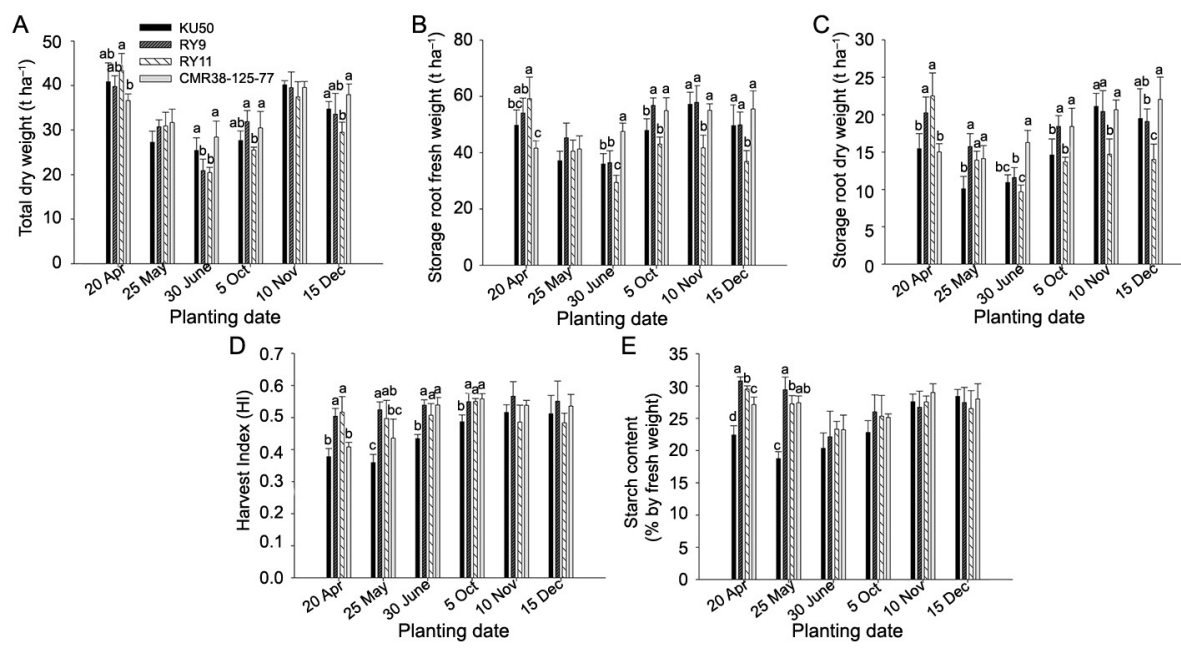

Figure 3 - Total dry weight (A), storage root fresh weight (B), storage root dry weight (C), harvest index (HI) (D) and starch content (by fresh weight) (E) at the final harvest of Kasetsart 50, Rayong 9, Rayong 11 and CMR38-125-77 grown at different planting dates. The same letters in each planting date are not significantly different by least significant difference $(p<0.05)$. Error bars indicate standard deviation of means.

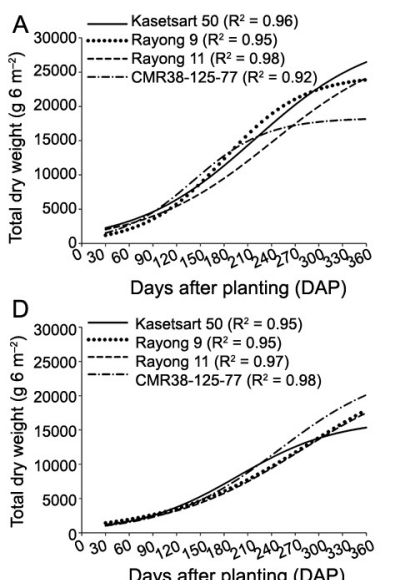

Days after planting (DAP)

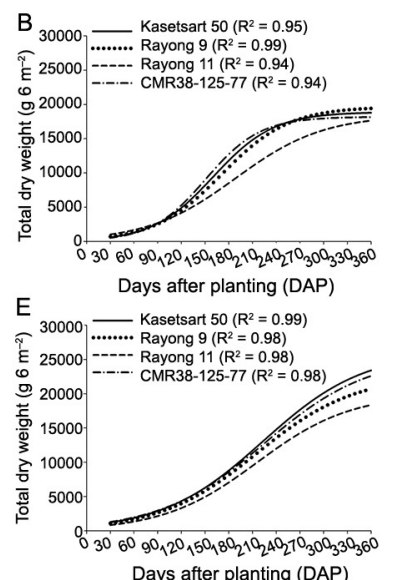

Days after planting (DAP)

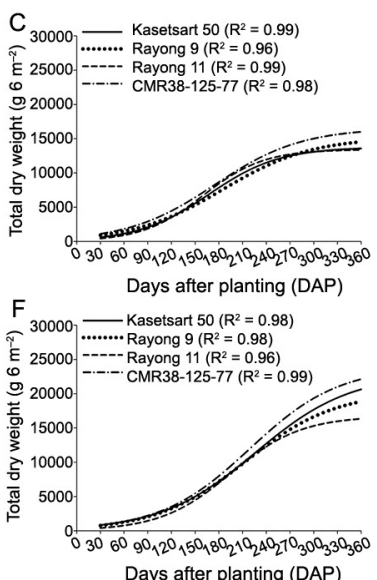

Days after planting (DAP)

Figure 4 - Growth pattern of Kasetsart 50, Rayong 9, Rayong 11 and CMR38-125-77 at 20 Apr (A), 25 May (B), 30 June (C), 5 Oct (D), 10 Nov (E) and $15 \mathrm{Dec}$ (F) planting dates. 
significant differences $(p<0.05)$ for all planting dates (Figure $3 \mathrm{~B}$ and $\mathrm{C}$ ). Each cassava genotype produced the best storage root dry weight for different planting dates. Considering all six planting dates, however, Rayong 9 and CMR38-125-77 represented superior genotypes in terms of storage root dry weight. The logistic curves (Figure 5A, B, C, D, E and F) indicated that CMR38-12577 produced high storage root dry weight accumulation for almost all planting dates, with the exception of 20 Apr. Rayong 9 appeared to be good for storage root dry weight accumulation for the planting dates of 25 May, 30 June, 5 Oct and 10 Nov. Significant differences $p<$ 0.05 ) between the four cassava genotypes in HI were recorded for 20 Apr, 25 May, 30 June and 5 Oct planting dates, and Rayong 9 showed high values of HI (Figure 3D). Non-significant differences between the four cassava genotypes in terms of starch content were recorded for most planting dates, with the exception of $20 \mathrm{Apr}(p$ $<0.05$ ) and 25 May ( $p<0.05$ ) (Figure 3E).

There were significant differences between the four cassava genotypes in CGR from 60 to 120 DAP for the planting dates of 5 Oct $(p<0.01)$ and 10 Nov $(p<0.05)$, and Kasetsart 50 had the highest values (Table 3). Highly significant differences between the four genotypes in CGR from 180 to 240 DAP were found for most planting dates $(p<0.01)$, except for the 15 Dec planting date $(p<$ 0.05), with the highest values in Rayong 9 for the 20 Apr, 25 May and 30 June planting dates. The highest values of CGR from 180 to 240 DAP for the 5 Oct, 10 Nov and 15 Dec planting dates were recorded for CMR38-125-77, Kasetsart 50 and Rayong 11, respectively. For CGR from 300 to 360 DAP, a non-significant difference was found only for the planting date of $10 \mathrm{Nov}$; other planting dates demonstrated highly significant differences $(p<0.01)$. Each genotype showed the best performance for different planting dates. Rayong 9 had the highest values of SRGR from 60 to 120 DAP with planting dates of $20 \mathrm{Apr}$ $(p<0.01)$ and 25 May $(p<0.05)$. There were significant differences between the four cassava genotypes in SRGR from 180 to 240 DAP for all planting dates $(p<0.01$ and $p<0.05)$. Rayong 9 was recorded as a genotype with the highest values of SRGR from 180 to 240 DAP for the 20 Apr, 25 May and 30 June planting dates, and CMR38-12577, Kasetsart 50 and Rayong 11 with 5 Oct, 10 Nov and 15 Dec planting dates, respectively. For SRGR from 300 to $360 \mathrm{DAP}$, significant differences between the four cassava genotypes were recorded for all six planting dates $(p$ $<0.01$ ). Rayong 11 was the best in terms of SRGR from 300 to 360 DAP for the 20 Apr and 25 May planting dates, while Kasetsart 50 gave the highest values for the 10 Nov and 15 Dec planting dates.

Table 2 - Temperatures and total solar radiation of 2015 and 2016 for the periods of 60-120, 180-240 and 300-360 days after planting (DAP) for six different planting dates at Khon Kaen, Thailand.

\begin{tabular}{|c|c|c|c|c|c|}
\hline Crop age & $\begin{array}{c}\text { Planting } \\
\text { date }\end{array}$ & $\begin{array}{c}\text { Maximum } \\
\text { temperature }\end{array}$ & $\begin{array}{c}\text { Minimum } \\
\text { temperature }\end{array}$ & $\begin{array}{c}\text { Average } \\
\text { temperature }\end{array}$ & $\begin{array}{l}\text { Total solar } \\
\text { radiation }\end{array}$ \\
\hline \multirow{7}{*}{$\begin{array}{l}60-120 \\
\text { DAP }\end{array}$} & & & $-{ }^{\circ} \mathrm{C}-$ & 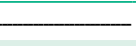 & $\mathrm{MJ} \mathrm{m}^{-2}$ \\
\hline & $20 \mathrm{Apr}$ & 39.7 & 22.8 & 28.5 & 1064.4 \\
\hline & 25 May & 36.6 & 22.8 & 27.5 & 1017.0 \\
\hline & 30 June & 36.9 & 20.7 & 27.2 & 993.3 \\
\hline & 5 Oct & 37.1 & 9.2 & 24.9 & 933.4 \\
\hline & $10 \mathrm{Nov}$ & 42.3 & 16.8 & 18.1 & 980.8 \\
\hline & $15 \mathrm{Dec}$ & 43.9 & 14.3 & 29.5 & 1033.3 \\
\hline \multirow{6}{*}{$\begin{array}{l}180-240 \\
\text { DAP }\end{array}$} & $20 \mathrm{Apr}$ & 37.7 & 13.8 & 26.8 & 1021.4 \\
\hline & 25 May & 37.7 & 9.2 & 25.6 & 926.0 \\
\hline & 30 June & 38.7 & 8.9 & 24.4 & 967.8 \\
\hline & 5 Oct & 43.9 & 22.2 & 31.5 & 1214.7 \\
\hline & $10 \mathrm{Nov}$ & 41.1 & 23.1 & 29.2 & 1094.8 \\
\hline & $15 \mathrm{Dec}$ & 38.7 & 22.2 & 28.2 & 1056.0 \\
\hline \multirow{6}{*}{$\begin{array}{l}300-360 \\
\text { DAP }\end{array}$} & $20 \mathrm{Apr}$ & 43.9 & 14.3 & 30.0 & 1058.1 \\
\hline & 25 May & 43.9 & 19.3 & 31.4 & 1140.9 \\
\hline & 30 June & 41.1 & 22.2 & 29.7 & 1155.8 \\
\hline & 5 Oct & 36.4 & 22.7 & 27.6 & 999.9 \\
\hline & $10 \mathrm{Nov}$ & 36.3 & 18.4 & 26.7 & 951.0 \\
\hline & $15 \mathrm{Dec}$ & 34.9 & 16.2 & 25.6 & 979.0 \\
\hline
\end{tabular}
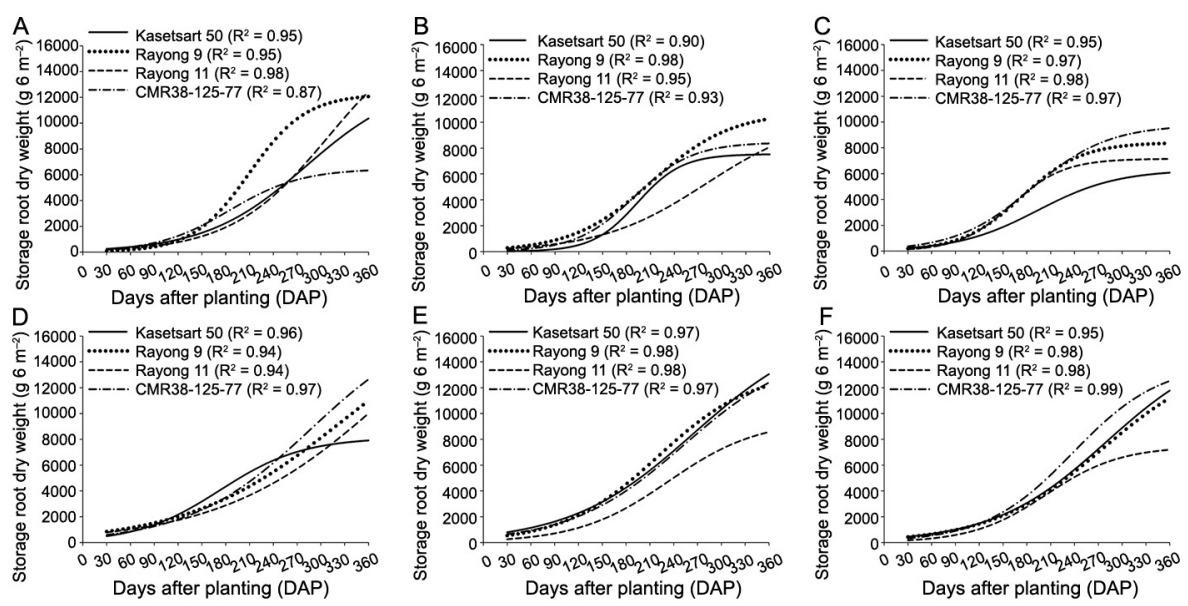

Figure 5 - Storage root growth pattern of Kasetsart 50, Rayong 9, Rayong 11 and CMR38-125-77 at 20 Apr (A), 25 May (B), 30 June (C), 5 Oct (D), $10 \mathrm{Nov}$ (E) and $15 \mathrm{Dec}$ (F) planting dates. 
Table 3 - Crop growth rate (CGR) and storage root growth rate (SRGR) for the periods of 60-120, 180-240 and 300-360 days after planting (DAP) of four cassava genotypes grown on six different planting dates.

\begin{tabular}{|c|c|c|c|c|c|c|c|}
\hline \multirow{2}{*}{ Crop age } & \multirow{2}{*}{ Genotype } & \multicolumn{3}{|c|}{ CGR $\left(\mathrm{g} \mathrm{m}^{-2} \mathrm{~d}^{-1}\right)$} & \multicolumn{3}{|c|}{ SRGR $\left(\mathrm{g} \mathrm{m}^{-2} \mathrm{~d}^{-1}\right)$} \\
\hline & & 60-120 DAP & $180-240$ DAP & 300-360 DAP & 60-120 DAP & $180-240$ DAP & 300-360 DAP \\
\hline \multirow{4}{*}{$20 \mathrm{Apr}$} & Kasetsart 50 & 14.6 & 1.3 & 13.6 & 2.1 & 4.3 & 9.7 \\
\hline & Rayong 9 & 16.2 & 30.3 & -10.8 & 5.1 & 19.4 & -10.6 \\
\hline & Rayong 11 & 14.6 & 17.5 & 13.9 & 2.6 & 10.3 & 14.1 \\
\hline & CMR38-125-77 & 15.3 & 10.9 & 16.6 & 2.5 & $7.5 b$ & 9.0 \\
\hline S.E. $(n=16)$ & & 1.37 & 1.37 & 0.87 & 0.43 & 0.91 & 0.47 \\
\hline LSD & & - & 6.28 & 4.00 & 1.95 & 4.19 & 2.18 \\
\hline F-test & & ns & $p<0.01$ & $p<0.01$ & $p<0.01$ & $p<0.01$ & $p<0.01$ \\
\hline C.V. (\%) & & 18.00 & 18.22 & 20.89 & 27.61 & 17.59 & 17.06 \\
\hline \multirow{4}{*}{25 May } & Kasetsart 50 & 13.7 & 10.5 & 4.2 & 3.4 & 11.9 & -0.8 \\
\hline & Rayong 9 & 13.2 & 19.5 & 3.8 & 4.8 & 11.8 & 4.2 \\
\hline & Rayong 11 & 11.0 & 7.9 & 9.0 & 2.3 & 4.7 & 7.9 \\
\hline & CMR38-125-77 & 14.5 & 9.0 & -19.7 & 3.8 & 4.3 & -7.3 \\
\hline S.E. $(n=16)$ & & 0.83 & 1.35 & 0.14 & 0.48 & 1.12 & 0.23 \\
\hline LSD & & - & 6.21 & 0.65 & 1.53 & 5.17 & 1.07 \\
\hline F-test & & ns & $p<0.01$ & $p<0.01$ & $p<0.05$ & $p<0.01$ & $p<0.01$ \\
\hline C.V. (\%) & & 12.76 & 23.05 & -40.63 & 26.89 & 27.57 & 46.61 \\
\hline \multirow{4}{*}{30 June } & Kasetsart 50 & 11.3 & 7.7 & -1.3 & 4.2 & 2.6 & 2.6 \\
\hline & Rayong 9 & 10.9 & 14.8 & 7.0 & 4.9 & 12.4 & 5.0 \\
\hline & Rayong 11 & 11.3 & 12.5 & -2.3 & 6.2 & 8.4 & -3.5 \\
\hline & CMR38-125-77 & 13.8 & 12.2 & 2.6 & 6.3 & 5.20 & 1.4 \\
\hline S.E. $(n=16)$ & & 0.91 & 0.98 & 0.35 & 0.58 & 0.92 & 0.17 \\
\hline LSD & & - & 4.53 & 1.60 & - & 4.23 & 0.80 \\
\hline F-test & & ns & $p<0.01$ & $p<0.01$ & ns & $p<0.01$ & $p<0.01$ \\
\hline C.V. (\%) & & 15.34 & 16.69 & 40.19 & 21.38 & 19.10 & 25.12 \\
\hline \multirow{4}{*}{5 Oct } & Kasetsart 50 & 10.8 & 3.6 & -4.8 & 6.5 & 3.3 & -1.1 \\
\hline & Rayong 9 & 9.6 & 4.0 & 4.6 & 5.3 & 2.2 & 6.5 \\
\hline & Rayong 11 & 8.6 & 3.3 & 7.3 & 4.3 & 3.3 & 8.7 \\
\hline & CMR38-125-77 & 6.3 & 12.9 & 5.4 & 3.4 & 5.8 & 9.9 \\
\hline S.E. $(n=16)$ & & 0.71 & 0.61 & 0.58 & 0.37 & 0.50 & 0.80 \\
\hline LSD & & 3.26 & 2.82 & 2.65 & 1.72 & 2.29 & 3.68 \\
\hline F-test & & $p<0.01$ & $p<0.01$ & $p<0.01$ & $p<0.01$ & $p<0.01$ & $p<0.01$ \\
\hline C.V. (\%) & & 16.07 & 20.60 & 36.67 & 15.33 & 27.49 & 26.71 \\
\hline \multirow{4}{*}{10 Nov } & Kasetsart 50 & 14.4 & 22.5 & 5.3 & 7.9 & 9.5 & 11.3 \\
\hline & Rayong 9 & 10.3 & 12.6 & 6.8 & 5.8 & 7.4 & 5.6 \\
\hline & Rayong 11 & 8.2 & 11.8 & 8.3 & 3.2 & 5.6 & 7.1 \\
\hline & CMR38-125-77 & 14.2 & 17.6 & 8.0 & 7.5 & 4.5 & 6.5 \\
\hline S.E. $(n=16)$ & & 1.14 & 1.88 & 1.07 & 0.84 & 0.91 & 0.81 \\
\hline LSD & & 3.64 & 8.66 & - & 2.68 & 2.91 & 3.72 \\
\hline F-test & & $p<0.05$ & $p<0.01$ & ns & $p<0.05$ & $p<0.05$ & $p<0.01$ \\
\hline C.V. (\%) & & 19.07 & 23.37 & 30.21 & 26.75 & 26.90 & 21.30 \\
\hline \multirow{4}{*}{$15 \mathrm{Dec}$} & Kasetsart 50 & 9.3 & 11.0 & 14.9 & 4.4 & 3.2 & 12.5 \\
\hline & Rayong 9 & 7.9 & 13.5 & 10.4 & 3.1 & 4.9 & 7.4 \\
\hline & Rayong 11 & 8.6 & 16.4 & 3.7 & 3.4 & 6.5 & 3.9 \\
\hline & CMR38-125-77 & 10.8 & 13.3 & -3.0 & 4.4 & 6.3 & 3.7 \\
\hline S.E. $(n=16)$ & & 0.72 & 0.87 & 1.44 & 0.47 & 0.72 & 0.89 \\
\hline LSD & & - & 2.79 & 6.62 & - & 2.30 & 4.07 \\
\hline F-test & & ns & $p<0.05$ & $p<0.01$ & ns & $p<0.05$ & $p<0.01$ \\
\hline C.V. (\%) & & 15.83 & 12.89 & 44.35 & 24.57 & 27.65 & 25.73 \\
\hline
\end{tabular}

S.E. $=$ standard error; $\mathrm{n}=$ number of observations; $\mathrm{LSD}=$ least significant difference; $\mathrm{C} . \mathrm{V} .=$ coefficient of variation; $\mathrm{ns}=$ not significant.

CMR38-125-77 had the highest values of SGR from 60 to $120 \mathrm{DAP}$, with statistical significance for the planting dates of 25 May $(p<0.01)$, 30 June $(p<0.01)$,
10 Nov $(p<0.05)$ and $15 \operatorname{Dec}(p<0.05)$ (Table 4). There were significant differences $(p<0.01$ and $p<0.05)$ between the four cassava genotypes in SGR from 180 
Table 4 - Stem growth rate (SGR) and leaf growth rate (LGR) for the periods of 60-120, 180-240 and 300-360 days after planting (DAP) of four cassava genotypes grown on six different planting dates.

\begin{tabular}{|c|c|c|c|c|c|c|c|}
\hline \multirow{2}{*}{ Crop age } & \multirow{2}{*}{ Genotype } & \multicolumn{3}{|c|}{ SGR $\left(\mathrm{g} \mathrm{m}^{-2} \mathrm{~d}^{-1}\right)$} & \multicolumn{3}{|c|}{ LGR $\left(\mathrm{g} \mathrm{m}^{-2} \mathrm{~d}^{-1}\right)$} \\
\hline & & 60-120 DAP & 180-240 DAP & 300-360 DAP & 60-120 DAP & 180-240 DAP & 300-360 DAP \\
\hline \multirow{4}{*}{$20 \mathrm{Apr}$} & Kasetsart 50 & 8.7 & 3.0 & 2.1 & 2.3 & -5.5 & 1.0 \\
\hline & Rayong 9 & 8.0 & 12.0 & -1.7 & 2.2 & -1.2 & 0.4 \\
\hline & Rayong 11 & 7.7 & 9.5 & 4.1 & 2.8 & -1.4 & -0.6 \\
\hline & CMR38-125-77 & 9.6 & 6.5 & 4.8 & 1.9 & -1.7 & 0.5 \\
\hline S.E. $(n=16)$ & & 0.79 & 1.01 & 0.41 & 0.18 & 0.12 & 0.08 \\
\hline LSD & & - & 4.64 & 1.89 & - & 0.83 & 0.38 \\
\hline F-test & & ns & $p<0.01$ & $p<0.01$ & ns & $p<0.01$ & $p<0.01$ \\
\hline C.V. (\%) & & 18.63 & 26.12 & 35.27 & 15.89 & -9.68 & 49.49 \\
\hline \multirow{4}{*}{25 May } & Kasetsart 50 & 6.3 & 5.1 & 3.0 & 3.2 & -1.6 & 1.5 \\
\hline & Rayong 9 & 4.8 & 9.9 & -6.2 & 2.1 & -0.8 & 1.0 \\
\hline & Rayong 11 & 5.1 & 5.3 & -2.4 & 2.4 & -1.2 & -0.3 \\
\hline & CMR38-125-77 & 7.2 & 6.2 & -10.4 & 2.3 & -0.3 & 0.3 \\
\hline S.E. $(n=16)$ & & 0.41 & 1.08 & 0.98 & 0.22 & 0.10 & 0.12 \\
\hline LSD & & 1.90 & 3.46 & 4.53 & - & 0.44 & 0.54 \\
\hline F-test & & $p<0.01$ & $p<0.05$ & $p<0.01$ & ns & $p<0.01$ & $p<0.01$ \\
\hline C.V. (\%) & & 14.10 & 21.44 & -49.32 & 15.55 & -19.57 & 37.32 \\
\hline \multirow{4}{*}{30 June } & Kasetsart 50 & 2.9 & 6.2 & 0.6 & 3.0 & 0.2 & 0.1 \\
\hline & Rayong 9 & 3.2 & 3.8 & 4.6 & 1.8 & -0.3 & 1.1 \\
\hline & Rayong 11 & 2.5 & 3.5 & 1.4 & 1.8 & 0.5 & -1.3 \\
\hline & CMR38-125-77 & 4.2 & 4.9 & 0.2 & 2.2 & 0.4 & 1.4 \\
\hline S.E. $(n=16)$ & & 0.22 & 0.55 & 0.24 & 0.24 & 0.17 & 0.06 \\
\hline LSD & & 1.01 & 1.75 & 1.11 & 0.76 & 0.55 & 0.28 \\
\hline F-test & & $p<0.01$ & $p<0.05$ & $p<0.01$ & $p<0.05$ & $p<0.05$ & $p<0.01$ \\
\hline C.V. (\%) & & 13.75 & 23.92 & 28.91 & 21.72 & 16.27 & 40.19 \\
\hline \multirow{4}{*}{5 Oct } & Kasetsart 50 & 1.6 & 1.1 & -2.6 & 1.8 & 0.3 & -1.6 \\
\hline & Rayong 9 & 2.0 & 2.3 & 1.5 & 1.5 & -0.1 & $-1.3 b$ \\
\hline & Rayong 11 & 1.9 & 1.6 & -1.4 & 1.5 & 0.6 & -1.0 \\
\hline & CMR38-125-77 & 1.7 & 3.2 & -2.0 & 0.8 & 0.3 & -0.7 \\
\hline S.E. $(n=16)$ & & 0.17 & 0.26 & 0.14 & 0.12 & 0.03 & 0.10 \\
\hline LSD & & - & 1.21 & 0.65 & 0.55 & 0.13 & 0.45 \\
\hline F-test & & ns & $p<0.01$ & $p<0.01$ & $p<0.01$ & $p<0.01$ & $p<0.01$ \\
\hline C.V. (\%) & & 18.46 & 25.80 & -25.15 & 17.03 & 22.81 & -17.24 \\
\hline \multirow{4}{*}{10 Nov } & Kasetsart 50 & 3.0 & 10.1 & 5.9 & 2.5 & 2.4 & -0.2 \\
\hline & Rayong 9 & 2.3 & 4.8 & 1.6 & 1.5 & -0.2 & -0.8 \\
\hline & Rayong 11 & 2.1 & 5.8 & 3.1 & 1.9 & 0.5 & -0.1 \\
\hline & CMR38-125-77 & 3.3 & 10.8 & 3.9 & 2.3 & 2.6 & -0.1 \\
\hline S.E. $(n=16)$ & & 0.28 & 1.11 & 0.48 & 0.11 & 0.18 & 0.04 \\
\hline LSD & & 0.89 & 5.08 & 2.21 & 0.50 & 0.82 & 0.17 \\
\hline F-test & & $p<0.05$ & $p<0.01$ & $p<0.01$ & $p<0.01$ & $p<0.01$ & $p<0.01$ \\
\hline C.V. (\%) & & 20.69 & 28.13 & 26.91 & 10.56 & 27.04 & -24.01 \\
\hline \multirow{4}{*}{$15 \mathrm{Dec}$} & Kasetsart 50 & 2.2 & 7.4 & 2.9 & 1.8 & 0.2 & -1.3 \\
\hline & Rayong 9 & 2.4 & 7.9 & 6.4 & 1.5 & 0.3 & -0.3 \\
\hline & Rayong 11 & 2.5 & 7.5 & 1.9 & 1.7 & 1.5 & -0.5 \\
\hline & CMR38-125-77 & 3.2 & 6.7 & -0.7 & 2.1 & 0.1 & -1.3 \\
\hline S.E. $(n=16)$ & & 0.17 & 0.61 & 0.43 & 0.14 & 0.04 & 0.10 \\
\hline LSD & & 0.54 & - & 1.99 & - & 0.20 & 0.47 \\
\hline F-test & & $p<0.05$ & ns & $p<0.01$ & ns & $p<0.01$ & $p<0.01$ \\
\hline C.V. (\%) & & 13.06 & 16.53 & 33.25 & 15.54 & 16.83 & -23.94 \\
\hline
\end{tabular}

S.E. $=$ standard error; $\mathrm{n}=$ number of observations; $\mathrm{LSD}=$ least significant difference; $\mathrm{C} . \mathrm{V} .=$ coefficient of variation; $\mathrm{ns}=$ not significant.

to 240 DAP for most planting dates, except for 15 Dec. Rayong 9 showed the highest values of SGR from 180 to 240 DAP for the $20 \mathrm{Apr}$ and 25 May planting dates, and CMR38-125-77 for the 5 Oct and 10 Nov planting dates.
Highly significant differences $(p<0.01)$ in SGR were observed between the four genotypes from 300 to 360 DAP. Kasetsart 50 was the best for SGR from 300 to 360 DAP for the 25 May and 10 Nov planting dates, and Ray- 
ong 9 for the 30 June, 5 Oct and 15 Dec planting dates. The highest values of LGR from 60 to 120 DAP with statistical significance were reported for Kasetsart 50 for the planting dates of 30 June $(p<0.05)$, 5 Oct $(p<0.01)$ and 10 Nov $(p<0.01)$. Rayong 11 produced the highest LGR from 180 to 240 DAP, with statistical significance for the 30 June $(p<0.05), 5$ Oct $(p<0.01)$ and 15 Dec $(p<0.01)$ planting dates, and CMR38-125-77 for the 25 May $(p<0.01)$ and 10 Nov $(p<0.01)$ planting dates. For LGR at 300-360 DAP, highly significant differences $(p<0.01)$ between the four cassava genotypes for all six different planting dates were recorded. Kasetsart 50 had the highest values of LGR from 300 to 360 DAP for the 20 Apr and 25 May planting dates, while CMR38-125-77 gave the highest values for the 30 June, 5 Oct and 10 Nov planting dates.

There were significant differences $(p<0.01$ and $p<0.05$ ) between the four cassava genotypes in LAI at 120, 240 and 300 DAP with all six planting dates, except for LAI at 300 DAP on the 15 Dec planting date (Table 5). Rayong 11 gave the highest values of LAI at 120,240 and 300 DAP on planting dates of 20 Apr and 25 May, while Kasetsart 50 showed good performance on planting dates of 5 Oct and 10 Nov. CMR38-125-77 had the highest values of SLA at 120 DAP, with statistical significance $(p<0.05)$ for the $20 \mathrm{Apr}, 30$ June and 10 Nov planting dates. Rayong 11 was the best in terms of SLA at 240 DAP, with statistical significance for the planting dates of 30 June $(p<0.01)$ and 10 Nov $(p<$ $0.01)$, and CMR38-125-77 for the 5 Oct $(p<0.05)$ planting date. For SLA at 300 DAP, there were significant differences $(p<0.01$ and $p<0.05)$ between the four cassava genotypes grown for the planting dates of 5 Oct and 10 Nov.

\section{Combined analysis and relationship between physiological traits and storage root yield}

The combined analysis of variance indicated a highly significant effect $(p<0.01)$ of planting dates (or growing dates), genotypes and planting date $\times$ genotype on almost all physiological traits (Table 6). The variations due to planting dates comprised the major part of the total variations for almost all crop traits. Planting date $\times$ genotype contributed to the greater part of the total variations for CGR from 180 to 240 DAP, CGR from 300 to 360 DAP, SRGR from 180 to 240 DAP and SRGR from 300 to 360 DAP.

The results of stepwise regression analysis (Table 7) indicated that total crop dry weight at final harvest could be explained by a combination of LAI at 120, 240 and 300 DAP, SLA at 120 DAP, SRGR at 300-360 DAP, LGR at 60-120 and 300-360 DAP, with the $\mathrm{R}^{2}$ value of 0.60 ( $p<0.05)$. However, the combination of LAI at 120 , 240 and 300 DAP, SLA at 120 and 240 DAP, CGR at 300360 DAP, SRGR at 300-360 DAP, SGR at 180-240 DAP, LGR at 60-120 and 300-360 DAP had the strongest relationship with storage root dry weight at final harvest, with an $\mathrm{R}^{2}$ value of $0.58(p<0.05)$.

\section{Discussion}

The study of CGR, SGR, LGR, SRGR, LAI and SLA during different growing periods, along with the dry weights of crop and storage root yield and $\mathrm{HI}$ at the final harvest of different cassava genotypes with varying planting dates provides more information concerning growth habit, as well as a better understanding of the adaptability and physiological determinants of storage root yield of cassava planted at different growing dates. The results from the combined analysis indicated that there were interactions between the six planting dates and the four cassava genotypes for almost all crop traits. These findings reveal that the effect of growing date differs significantly with the tested genotypes for most crop traits. The six different planting dates had a statistically significant effect on all crop traits and constituted the major part of the total variations for certain crop traits, except for CGR at 180-240 DAP, CGR at 300-360 DAP, SRGR at 180-240 DAP and SRGR at 300-360 DAP. The differences in crop traits between the six planting dates were expected due to weather factors, such as temperature and solar radiation, during the growing dates. Lower values for average air temperature and solar radiation during the period $1 \mathrm{Dec}$ to 1 Mar 2016 (during the cool season; average temperature range 12.3 - $29.6{ }^{\circ} \mathrm{C}$; solar radiation range 7.9 - $19.3 \mathrm{MJ} \mathrm{m}^{-2} \mathrm{~d}^{-1}$ ) relate to a lower accumulation rate and a shorter period for the linear phase for total biomass for the 30 June planting date. The cool season conditions also reduced total biomass accumulation rates during the early growth period and exponential phase for the 5 Oct, 10 Nov and 15 Dec planting dates. However, high temperatures and solar radiation during the hot and rainy seasons supported high total biomass productions in the linear phase or grand period of growth for the 5 Oct, 10 Nov and 15 Dec planting dates. Similar results and supported reasons were also found for storage root accumulation (El-Sharkawy, 1993). An air temperature below $20{ }^{\circ} \mathrm{C}$ decreased photosynthesis, growth and storage root weight of cassava (El-Sharkawy, 2006; El-Sharkawy, 2012). A study by Keating et al. (1982a), conducted in Queensland, Australia $\left(27^{\circ} 37^{\prime} \mathrm{S}\right.$ and $153^{\circ} 19^{\prime} \mathrm{E}, 5 \mathrm{~m}$ a.l.s.) indicated that both the mean air temperature and solar radiation were correlated with CGR of cassava. Increasing the mean air temperature from $14^{\circ} \mathrm{C}$ to $26^{\circ} \mathrm{C}$ and solar radiation from $11 \mathrm{MJ} \mathrm{m}^{-2} \mathrm{~d}^{-1}$ to $23 \mathrm{MJ} \mathrm{m}^{-2} \mathrm{~d}^{-1}$ could improve the GCR of M Aus 10 genotype. However, Keating et al. (1982b) reported that little change in storage root growth rate for cassava genotype $M$ Aus 10 occurred with a mean air temperature range of $13-25{ }^{\circ} \mathrm{C}$ in Queensland, Australia $\left(27^{\circ} 37^{\prime} \mathrm{S}\right.$ and $153^{\circ} 17^{\prime} \mathrm{E}, 45 \mathrm{~m}$ a.l.s.). With regard to the effect of solar radiation on crop growth, previous studies have also reported that a large amount of solar radiation during the planting period resulted in an increase in total crop and storage root dry weights in cassava (Fukai et al., 1984a, b) and other crops, such as peanut (Phakamas et al., 2013), soybean (Banterng et al., 2010) and rice 
Table 5 - Leaf area index (LAl) and specific leaf area (SLA) at 120, 240, 300 days after planting (DAP) of four cassava genotypes grown on six different planting dates.

\begin{tabular}{|c|c|c|c|c|c|c|c|}
\hline \multirow{2}{*}{ Crop age date } & \multirow{2}{*}{ Genotype } & \multicolumn{3}{|c|}{ LAI $\left(\mathrm{cm}^{2} \mathrm{~cm}^{-2}\right)$} & \multicolumn{3}{|c|}{$\operatorname{SLA}\left(\mathrm{cm}^{2} \mathrm{~g}^{-1}\right)$} \\
\hline & & $120 \mathrm{DAP}$ & 240 DAP & 300 DAP & 120 DAP & 240 DAP & 300 DAP \\
\hline \multirow{4}{*}{$20 \mathrm{Apr}$} & Kasetsart 50 & 5.8 & 3.0 & 1.8 & 287.0 & 239.6 & 190.1 \\
\hline & Rayong 9 & 5.7 & 4.1 & 1.7 & 330.2 & 213.3 & 179.1 \\
\hline & Rayong 11 & 8.7 & 5.0 & 3.8 & 332.4 & 252.9 & 201.5 \\
\hline & CMR38-125-77 & 5.9 & 3.0 & 1.9 & 335.2 & 240.1 & 217.0 \\
\hline S.E. $(n=16)$ & & 0.33 & 0.17 & 0.17 & 10.00 & 13.82 & 13.58 \\
\hline LSD & & 1.51 & 0.79 & 0.79 & 31.99 & - & - \\
\hline F-test & & $p<0.01$ & $p<0.01$ & $p<0.01$ & $p<0.05$ & ns & ns \\
\hline C.V. (\%) & & 9.74 & 9.09 & 14.98 & 6.23 & 11.69 & 13.79 \\
\hline \multirow{4}{*}{25 May } & Kasetsart 50 & 6.8 & 3.5 & 1.9 & 334.1 & 229.2 & 212.3 \\
\hline & Rayong 9 & 5.2 & 2.7 & 1.2 & 326.7 & 205.8 & 186.0 \\
\hline & Rayong 11 & 8.1 & 4.4 & 4.4 & 459.1 & 253.0 & 212.1 \\
\hline & CMR38-125-77 & 7.3 & 4.3 & 1.4 & 409.9 & 252.0 & 186.2 \\
\hline S.E. $(n=16)$ & & 0.56 & 0.22 & 0.15 & 35.71 & 16.55 & 9.15 \\
\hline LSD & & 1.79 & 1.01 & 0.69 & - & - & - \\
\hline F-test & & $p<0.05$ & $p<0.01$ & $p<0.01$ & ns & ns & ns \\
\hline C.V. (\%) & & 16.37 & 11.87 & 13.44 & 18.68 & 14.09 & 9.19 \\
\hline \multirow{4}{*}{30 June } & Kasetsart 50 & 3.9 & 3.7 & 3.4 & 208.0 & 211.0 & 216.6 \\
\hline & Rayong 9 & 2.9 & 1.5 & 1.7 & 240.7 & 182.7 & 208.7 \\
\hline & Rayong 11 & 3.1 & 4.1 & 4.7 & 237.7 & 233.3 & 243.5 \\
\hline & CMR38-125-77 & 4.6 & 2.4 & 2.7 & 282.5 & 201.1 & 272.6 \\
\hline S.E. $(n=16)$ & & 0.27 & 0.14 & 0.40 & 14.60 & 7.15 & 25.07 \\
\hline LSD & & 1.26 & 0.66 & 1.85 & 46.72 & 32.88 & - \\
\hline F-test & & $p<0.01$ & $p<0.01$ & $p<0.01$ & $p<0.05$ & $p<0.01$ & ns \\
\hline C.V. (\%) & & 15.13 & 10.49 & 25.90 & 12.06 & 6.91 & 21.30 \\
\hline \multirow{4}{*}{5 Oct } & Kasetsart 50 & 2.7 & 4.0 & 6.9 & 194.6 & 209.6 & 279.5 \\
\hline & Rayong 9 & 2.3 & 2.3 & 3.4 & 193.0 & 187.5 & 200.2 \\
\hline & Rayong 11 & 2.3 & 3.7 & 5.4 & 191.5 & 237.9 & 272.6 \\
\hline & CMR38-125-77 & $1.8 \mathrm{c}$ & 4.2 & 3.7 & 205.63 & 247.9 & 243.9 \\
\hline S.E. $(n=16)$ & & 0.13 & 0.18 & 0.30 & 4.48 & 10.58 & 8.09 \\
\hline LSD & & 0.58 & 0.57 & 1.37 & - & 33.84 & 37.20 \\
\hline F-test & & $p<0.01$ & $p<0.05$ & $p<0.01$ & ns & $p<0.05$ & $p<0.01$ \\
\hline C.V. (\%) & & 11.22 & 10.03 & 12.25 & 4.57 & 9.58 & 6.50 \\
\hline \multirow{4}{*}{10 Nov } & Kasetsart 50 & 3.5 & 7.1 & 4.3 & 191.6 & 237.8 & 249.1 \\
\hline & Rayong 9 & 2.3 & 3.7 & 2.7 & 191.0 & 204.8 & 212.4 \\
\hline & Rayong 11 & 2.5 & 6.5 & 3.9 & 184.0 & 276.2 & 252.6 \\
\hline & CMR38-125-77 & 3.7 & 6.8 & 3.4 & 215.3 & 264.1 & 275.8 \\
\hline S.E. $(n=16)$ & & 0.17 & 0.49 & 0.23 & 5.21 & 8.75 & 13.13 \\
\hline LSD & & 0.78 & 2.27 & 1.04 & 16.68 & 40.22 & 42.02 \\
\hline F-test & & $p<0.01$ & $p<0.01$ & $p<0.01$ & $p<0.05$ & $p<0.01$ & $p<0.05$ \\
\hline C.V. (\%) & & 11.29 & 16.41 & 12.66 & 5.33 & 7.12 & 10.62 \\
\hline \multirow{4}{*}{$15 \mathrm{Dec}$} & Kasetsart 50 & 2.5 & 5.6 & 3.6 & 194.1 & 260.2 & 231.5 \\
\hline & Rayong 9 & 2.1 & 5.2 & 3.1 & 205.3 & 258.5 & 253.6 \\
\hline & Rayong 11 & 2.5 & 6.8 & 3.3 & 211.1 & 275.6 & 248.1 \\
\hline & CMR38-125-77 & 2.9 & 4.6 & 3.5 & 214.0 & 280.0 & 247.9 \\
\hline S.E. $(n=16)$ & & 0.15 & 0.15 & 0.14 & 5.88 & 8.75 & 14.51 \\
\hline LSD & & 0.47 & 0.68 & - & - & - & - \\
\hline F-test & & $p<0.05$ & $p<0.01$ & ns & ns & ns & ns \\
\hline C.V. (\%) & & 11.79 & 5.37 & 8.43 & 5.71 & 6.51 & 11.84 \\
\hline
\end{tabular}

S.E. = standard error; $n=$ number of observations; $L S D=$ least significant difference; C.V. $=$ coefficient of variation; $n s=$ not significant.

(Phakamas et al., 2013; Vilayvong et al., 2015). In the Patia Valley, in southwestern Colombia $\left(2^{\circ} 09^{\prime} \mathrm{N}\right.$ and $77^{\circ} 04^{\prime}$ $\mathrm{W}, 600 \mathrm{~m}$ a.1.s.), which is characterized by high solar radiation (22 $\left.\mathrm{MJ} \mathrm{m}^{-2} \mathrm{~d}^{-1}\right)$, high mean annual temperature $\left(28{ }^{\circ} \mathrm{C}\right)$ and high atmospheric humidity $(70 \%)$ conditions near optimal for high photosynthesis and growth, a dry root yield in ten months of $27 \mathrm{t} \mathrm{ha}^{-1}$ was experimentally obtained (El-Sharkawy et al., 1990; El-Sharkawy, 1993). 
Table 6 - Mean squares from combined analysis for physiological traits of four cassava genotypes grown on six different planting dates.

\begin{tabular}{|c|c|c|c|c|c|c|c|c|}
\hline \multirow{3}{*}{$\begin{array}{l}\text { Physiological traits } \\
\text { LAl at } 120 \text { DAP }\left(\mathrm{cm}^{2} \mathrm{~cm}^{-2}\right)\end{array}$} & \multicolumn{8}{|c|}{ Source of variation } \\
\hline & \multicolumn{2}{|c|}{ Planting date (PD) } & \multirow{2}{*}{$\begin{array}{c}\text { Replication/PD } \\
0.94\end{array}$} & \multicolumn{2}{|c|}{ Genotype (G) } & \multicolumn{2}{|c|}{$\mathrm{G} \times \mathrm{PD}$} & \multirow{2}{*}{$\begin{array}{c}\text { Pool error } \\
0.37\end{array}$} \\
\hline & 70.35 & $p<0.01$ & & 5.25 & $p<0.01$ & 1.93 & $p<0.01$ & \\
\hline LAl at 240 DAP $\left(\mathrm{cm}^{2} \mathrm{~cm}^{-2}\right)$ & 25.94 & $p<0.01$ & 0.23 & 14.80 & $p<0.01$ & 2.61 & $p<0.01$ & 0.26 \\
\hline LAl at 300 DAP $\left(\mathrm{cm}^{2} \mathrm{~cm}^{-2}\right)$ & 14.89 & $p<0.01$ & 0.58 & 18.32 & $p<0.01$ & 2.63 & $p<0.01$ & 0.25 \\
\hline SLA at 120 DAP $\left(\mathrm{cm}^{2} \mathrm{~g}^{-1}\right)$ & 96453.40 & $p<0.01$ & 675.50 & 9018.30 & $p<0.01$ & 2830.80 & $p<0.01$ & 1113.70 \\
\hline SLA at 240 DAP $\left(\mathrm{cm}^{2} \mathrm{~g}^{-1}\right)$ & 7136.50 & $p<0.01$ & 428.20 & 10001.00 & $p<0.01$ & 473.60 & ns & 520.80 \\
\hline SLA at 300 DAP $\left(\mathrm{cm}^{2} \mathrm{~g}^{-1}\right)$ & 9502.64 & $p<0.01$ & 645.33 & 5769.55 & $p<0.01$ & 1571.54 & ns & 896.81 \\
\hline CGR for $60-120$ DAP $\left(\mathrm{g} \mathrm{m}^{-2} \mathrm{~d}^{-1}\right)$ & 92.21 & $p<0.01$ & 4.73 & 21.06 & $p<0.01$ & 9.81 & $p<0.01$ & 3.80 \\
\hline CGR for $180-240$ DAP $\left(\mathrm{g} \mathrm{m}^{-2} \mathrm{~d}^{-1}\right)$ & 205.67 & $p<0.01$ & 19.90 & 166.83 & $p<0.01$ & 155.45 & $p<0.01$ & 6.23 \\
\hline CGR for 300-360 DAP $\left(\mathrm{g} \mathrm{m}^{-2} \mathrm{~d}^{-1}\right)$ & 202.08 & $p<0.01$ & 8.84 & 110.98 & $p<0.01$ & 330.36 & $p<0.01$ & 2.98 \\
\hline SRGR for 60-120 DAP $\left(\mathrm{g} \mathrm{m}^{-2} \mathrm{~d}^{-1}\right)$ & 23.81 & $p<0.01$ & 1.53 & 5.67 & $p<0.01$ & 6.52 & $p<0.01$ & 1.20 \\
\hline SRGR for $180-240$ DAP $\left(\mathrm{g} \mathrm{m}^{-2} \mathrm{~d}^{-1}\right)$ & 87.45 & $p<0.01$ & 9.29 & 86.96 & $p<0.01$ & 53.30 & $p<0.01$ & 3.02 \\
\hline SRGR for 300-360 DAP $\left(\mathrm{g} \mathrm{m}^{-2} \mathrm{~d}^{-1}\right)$ & 128.77 & $p<0.01$ & 5.98 & 58.65 & $p<0.01$ & 167.79 & $p<0.01$ & 1.59 \\
\hline SGR for 60-120 DAP $\left(\mathrm{g} \mathrm{m}^{-2} \mathrm{~d}^{-1}\right)$ & 105.62 & $p<0.01$ & 0.87 & 7.31 & $p<0.01$ & 0.98 & ns & 0.65 \\
\hline SGR for $180-240$ DAP $\left(\mathrm{g} \mathrm{m}^{-2} \mathrm{~d}^{-1}\right)$ & 78.17 & $p<0.01$ & 4.90 & 8.62 & $p<0.05$ & 23.56 & $p<0.01$ & 2.98 \\
\hline SGR for 300-360 DAP $\left(\mathrm{g} \mathrm{m}^{-2} \mathrm{~d}^{-1}\right)$ & 130.36 & $p<0.01$ & 4.03 & 29.75 & $p<0.01$ & 41.98 & $p<0.01$ & 1.09 \\
\hline LGR for 60-120 DAP $\left(\mathrm{g} \mathrm{m}^{-2} \mathrm{~d}^{-1}\right)$ & 2.03 & $p<0.01$ & 0.37 & 1.67 & $p<0.01$ & 0.51 & $p<0.01$ & 0.12 \\
\hline LGR for $180-240$ DAP $\left(\mathrm{g} \mathrm{m}^{-2} \mathrm{~d}^{-1}\right)$ & 28.33 & $p<0.01$ & 0.21 & 4.16 & $p<0.01$ & 5.00 & $p<0.01$ & 0.06 \\
\hline LGR for 300-360 DAP $\left(\mathrm{g} \mathrm{m}^{-2} \mathrm{~d}^{-1}\right)$ & 8.14 & $p<0.01$ & 0.04 & 2.42 & $p<0.01$ & 2.01 & $p<0.01$ & 0.03 \\
\hline Total dry weight $\left(\mathrm{t} \mathrm{ha}^{-1}\right)^{*}$ & 637.57 & $p<0.01$ & 8.65 & 34.21 & $p<0.01$ & 31.66 & $p<0.01$ & 7.29 \\
\hline Storage root fresh weight $\left(\mathrm{t} \mathrm{ha}^{-1}\right)^{*}$ & 625.25 & $p<0.01$ & 20.97 & 339.46 & $p<0.01$ & 158.82 & $p<0.01$ & 21.13 \\
\hline Storage root dry weight $\left(\mathrm{t} \mathrm{ha}^{-1}\right)^{*}$ & 139.76 & $p<0.01$ & 5.29 & 57.59 & $p<0.01$ & 31.71 & $p<0.01$ & 3.64 \\
\hline Starch content (\% by fresh weight) ${ }^{*}$ & 73.73 & $p<0.01$ & 3.65 & 70.16 & $p<0.01$ & 19.22 & $p<0.01$ & 3.83 \\
\hline $\mathrm{H}^{*}$ & 0.02 & $p<0.01$ & 0.00 & 0.03 & $p<0.01$ & 0.01 & $p<0.01$ & 0.00 \\
\hline
\end{tabular}

Table 7 - Stepwise regressions between physiological traits and dry weights of total crop and storage root at final harvest for four cassava genotypes grown on six different planting dates.

\begin{tabular}{|c|c|c|c|c|}
\hline Variable & Coefficient & $p$-value & Determination coefficient $\left(\mathrm{R}^{2}\right)$ & $p$-value for regression \\
\hline \multicolumn{5}{|l|}{ Total crop dry weight } \\
\hline Constant & 42.84 & $0.00(p<0.01)$ & \multirow{8}{*}{0.60} & \multirow{8}{*}{$p<0.05$} \\
\hline LAl at 120 DAP & 4.27 & $0.00(p<0.01)$ & & \\
\hline LAl at 240 DAP & 1.46 & $0.00(p<0.01)$ & & \\
\hline LAl at 300 DAP & -2.41 & $0.00(p<0.01)$ & & \\
\hline SLA at 120 DAP & -0.08 & $0.00(p<0.01)$ & & \\
\hline SRGR for 300-360 DAP & 0.24 & $0.00(p<0.01)$ & & \\
\hline LGR for 60-120 DAP & -3.92 & $0.00(p<0.01)$ & & \\
\hline LGR for 300-360 DAP & -2.60 & $0.00(p<0.01)$ & & \\
\hline \multicolumn{3}{|l|}{ Storage root dry weight } & \multirow{12}{*}{0.58} & \multirow{12}{*}{$p<0.05$} \\
\hline Constant & 27.93 & $0.00(p<0.01)$ & & \\
\hline LAl at 120 DAP & 1.56 & $0.00(p<0.01)$ & & \\
\hline LAl at 240 DAP & 0.77 & $0.01(p<0.05)$ & & \\
\hline LAl at 300 DAP & -0.94 & $0.01(p<0.05)$ & & \\
\hline SLA at 120 DAP & -0.03 & $0.00(p<0.01)$ & & \\
\hline SLA at 240 DAP & -0.03 & $0.03(p<0.05)$ & & \\
\hline CGR for 300-360 DAP & -0.19 & $0.01(p<0.05)$ & & \\
\hline SRGR for 300-360 DAP & 0.43 & $0.00(p<0.01)$ & & \\
\hline SGR for $180-240$ DAP & 0.53 & $0.00(p<0.01)$ & & \\
\hline LGR for 60-120 DAP & -3.63 & $0.00(p<0.01)$ & & \\
\hline LGR for 300-360 DAP & -1.48 & $0.01(p<0.05)$ & & \\
\hline
\end{tabular}

Stepwise regression analysis showed that LAI at 120, 240 and 300 DAP, SLA at 120 DAP, SRGR from 300 to 360 DAP, LGR from 60 to 120 DAP and LGR from 300 to 360 DAP were the physiological determinants of total crop dry weight at final harvest. As the results of both separate analyses of variance and logistic curves for all planting dates showed Kasetsart 50 and CMR38125-77 were generally good for total crop dry weight 
production. High values for total crop dry weights in Kasetsart 50 correlated with high values for LAI at 120 and 240 DAP and SRGR from 300 to 360 DAP, whereas high total crop dry weights for CMR38-125-77 correlated to high values of LAI at 120 DAP. The results of the stepwise regression analysis showed that the physiological determinant of storage root dry weight at final harvest was a combination of LAI at 120, 240 and 300 DAP, SLA at 120 and 240 DAP, CGR at 300-360 DAP, SRGR at 300-360 DAP, SGR at 180-240 DAP, LGR at 60-120 DAP and LGR at 300-360 DAP. These findings confirm the importance of leaf area duration and leaf retention as selection criteria for genotype stability across seasonal variations (El-Sharkawy et al., 1992; Lenis et al., 2006). Rayong 9 and CMR38-125-77 would be desirable genotypes based on final storage root and storage root dry weight accumulation for nearly all planting dates. An increase in the storage root dry weight at the final harvest related to high values for LAI at 120 DAP and SGR from 180 to 240 DAP for CMR38-125-77, and SGR from 180 to 240 DAP for Rayong 9.

Based on final harvest data for all six planting dates, the results of this study showed that CMR38125-77 performed well in terms of mean values for both total crop and storage root dry weights (34.1 and $17.7 \mathrm{t} \mathrm{ha}^{-1}$, respectively). For the 20 Apr planting date, however, total crop and storage root dry weights of CMR38-125-77 were rather low and can be attributed to the short duration of the linear phase, while Rayong 11 gave the highest values with a long duration of the linear phase. Overall, CMR38-125-77 represented an alternative genotype for almost all planting dates, and Rayong 11 was good for the 20 Apr planting date. These two cassava genotypes would also be suitable parental sources for improving cassava varieties in order to maximize both total crop and storage root dry weight. Crop traits during the early growth stage of cassava (LAI at 120 DAP, SLA at 120 DAP and LGR during 60-120 DAP), as well as leaf growth during the late growing period (LAI at 240 and 300 DAP and LGR at 300-360 DAP), were the components of physiological determinants of both total crop and storage root dry weights at final harvest. Leaf is an important source for growth of the storage root in cassava. High LAI values in cassava resulted in an increase in crop photosynthesis, growth and final storage root yield (El-Sharkawy et al., 1992; Lahai et al., 1999; El-Sharkawy and De Tafur, 2010; Phuntupan and Banterng, 2017). The maximum LAI in cassava varied from four to eight, depending on the genotype and the environmental conditions during crop growth (Cock, 1985). However, Ramanujam (1985) reported that low-yielding genotypes maintain LAI values less than 2 and greater than 4 which reduced light use efficiency. The leaf areas of cassava and storage roots grow simultaneously, and photosynthetic carbon assimilation is partitioned between these two organs (Lebot, 2009). For SLA, previous studies have indicated that decreased SLA can enhance cas- sava photosynthesis $\left(\mathrm{CO}_{2}\right.$ uptake) and, thus, results in greater crop growth capacity (El-Sharkawy et al., 1992; Phuntupan and Banterng, 2017). SRGR from 300 to 360 DAP (the late growing period) was also a component of the physiological determinants of storage root dry weight at final harvest. A positive correlation between storage root yield and tuberous root bulking rate of cassava has also been reported by Lahai et al. (1999). A previous study demonstrated that SRGR from 180 to 210 DAP greatly contributed to the variation in storage root dry weight at the final harvest of cassava grown under a different nitrogen fertiliser application rate (Phuntupan and Banterng, 2017). Therefore, these physiological traits could be used to describe how particular cassava genotypes function for different growing dates.

This study showed how different cassava genotypes perform for different growing dates. The study of physiological traits in relation to yield performance and enhancement of cassava growth under different growing conditions could facilitate a better understanding of crop performance for different environments and the selection of physiological traits and suitable management practices for improving crop productivity (Phuntupan and Banterng, 2017). In addition, an assessment of physiological traits and their impact on crop yield has significant implications for the design of new plant types for profitable yield potential for particular environments. These physiological traits also involve the application of crop simulation models as a tool for the development of new ideotypes (Boote et al., 2001; Jones et al., 2003; White and Hoogenboom, 2003; Ghanem et al., 2015) in support of the cassava improvement program and ultimately increase the efficiency of cassava breeding for specific environments.

\section{Conclusions}

There were significant differences between the six growing dates for all crop traits contributing to the largest variations for most crop traits, except for CGR from 180 to 240 DAP, CGR from 300 to 360 DAP, SRGR from 180 to 240 DAP and SRGR from 300 to 360 DAP. Low values of daily temperatures and solar radiation during the cool season for the 30 June planting date were associated with low accumulation rates and short periods in linear phases for total biomass and storage root. Based on mean values for six planting dates, CMR38-125-77 seems to be a good genotype in terms of total crop and storage root dry weights at the final harvest for most planting dates, except for the 20 Apr planting date for which Rayong 11 was the best. The crop traits (LAI at 120,240 and 300 DAP, SLA at 120 DAP, SRGR from 300 to 360 DAP, LGR from 60 to 120 DAP and LGR from 300 to 360 DAP) were the components of physiological determinants of both total crop and storage root dry weights at final harvest. 


\section{Acknowledgments}

This study was supported by the Thailand Research Fund through the Thai Royal Golden Jubilee Ph.D. Program (Grant no. PHD/0012/2557), the National Science and Technology Development Agency (NSTDA), Thailand. Assistance in conducting the work was also provided by the Plant Breeding Research Center for Sustainable Agriculture, Khon Kaen University, Thailand. Acknowledgment is extended to the Thailand Research Fund (Project code: IRG5780003) and Faculty of Agriculture, Khon Kaen University for providing financial support for manuscript preparation activities. The authors appreciate editing support provided by Dr. Carol J. Wilkerson.

\section{Authors' Contributions}

Conceptualization: Phoncharoen, P.; Banterng, P.; Vorasoot, N.; Jogloy, S.; Theerakulpisut, P. Data acquisition: Phoncharoen, P.; Banterng, P. Data analysis: Phoncharoen, P.; Banterng, P. Design of methodology: Phoncharoen, P.; Banterng, P.; Vorasoot, N.; Jogloy, S.; Theerakulpisut, P. Writing and Editing: Phoncharoen, P.; Banterng, P.; Vorasoot, N.; Jogloy, S.; Theerakulpisut, P.; Hoogenboom, G.

\section{References}

Alves, A.A.C. 2002. Cassava botany and physiology. p. 67-89. In: Hillocks, R.J.; Thresh, J.M.; Bellotti, A.C., eds. Cassava: biology, production and utilization. CABI, Wallingford, UK.

Aye, T.M. 2012. Cassava agronomy: land preparation, time and method of planting and harvest, plant spacing and weed control. p. 588-612. In: Howeler, R.H., ed. The cassava handbook: a reference manual based on the Asian regional cassava training course held in Thailand. CIAT, Bangkok, Thailand.

Banterng, P.; Hoogenboom, G.; Patanothai, A.; Singh, P.; Wani, S.P.; Pathak, P.; Tongpoonpol, S.; Atichart, S.; Srihaban, P.; Buranaviriyakul, S.; Jintrawet, A.; Nguyen, T.C. 2010. Application of the cropping system model (CSM)-CROPGROSoybean for determining optimum management strategies for soybean in tropical environments. Journal of Agronomy and Crop Science 196: 231-242.

Banterng, P.; Patanothai, A.; Pannangpetch, K.; Jogloy, S.; Hoogenboom, G. 2003. Seasonal variation in the dynamic growth and development traits of peanut lines. The Journal of Agricultural Science 141: 51-62.

Banterng, P.; Patanothai, A.; Pannangpetch, K.; Jogloy, S.; Hoogenboom, G. 2006. Yield stability evaluation of peanut lines: a comparison of an experimental versus a simulation approach. Field Crops Research 96: 168-175.

Boote, K.J.; Kropff, M.J.; Bindraban, P.S. 2001. Physiology and modelling of traits in crop plants: implications for genetic improvement. Agricultural Systems 70: 395-420.

Cock, J.H. 1985. Cassava: New Potential for a Neglected Crop. Westview Press, Boulder, CO, USA.
Cock, J.H.; Franklin, D.; Sandoval, G.; Juri, P. 1979. The ideal cassava plant for maximum yield. Crop Science 19: 271-279.

El-Sharkawy, M.A. 1993. Drought-tolerant cassava for Africa, Asia, and Latin America. BioScience 43: 441-451.

El-Sharkawy, M.A. 2006. International research on cassava photosynthesis, productivity, eco-physiology, and responses to environmental stresses in the tropics. Photosynthetica 44: 481512.

El-Sharkawy, M.A. 2012. Stress tolerant cassava: the role of integrative ecophysiology breeding research in crop improvement. Open Journal of Soil Science 2: 162-186.

El-Sharkawy, M.A.; Cock, J.H.; Lynam, J.K.; Hernandez, A.D.P.; Cadavid L.L.F. 1990. Relationships between biomass, root-yield and single-leaf photosynthesis in field-grown cassava. Field Crops Research 25: 183-201.

El-Sharkawy, M.A.; De Tafur, S.M. 2010. Comparative photosynthesis, growth, productivity, and nutrient use efficiency among tall- and short-stemmed rain-fed cassava cultivars. Photosynthetica 48: 173-188.

El-Sharkawy, M.A.; Hernandez, A.D.P.; Hershey, C. 1992. Yield stability of cassava during prolonged mid-season water stress. Experimental Agriculture 28: 165-174.

Fukai, S.; Alcoy, A.B.; Llamelo, A.B.; Patterson, R.D. 1984a. Effects of solar radiation on growth of cassava (Manihot esculenta Crantz.). I. Canopy development and dry matter growth. Field Crops Research 9: 347-360.

Fukai, S.; Alcoy, A.B.; Llamelo, A.B.; Patterson, R.D. 1984b. Effects of solar radiation on growth of cassava (Manihot esculenta Crantz). II. Fibrous root length. Field Crops Research 9: 361-371.

Ghanem, M.E.; Marrou, H.; Sinclair, T.R. 2015. Physiological phenotyping of plants for crop improvement. Trends in Plant Science 20: 139-144.

Howeler, R.H. 2002. Cassava mineral nutrition and fertilization. p. 115-147. In: Hillocks, R.J.; Thresh, J.M.; Bellotti, A.C., eds. Cassava: biology, production and utilization. CABI, Wallingford, UK.

Howeler, R.H. 2014. Sustainable soil and crop management of cassava in Asia. CIAT, Cali, Colombia.

Irikura, V.; Cock, J.H.; Kawano, K. 1979. The physiological basis of genotype-temperature interactions in cassava. Field Crops Research 2: 227-239.

Jennings, D.L.; Iglesias, C. 2002. Breeding for improvement. p. 149166. In: Hillocks, R.J.; Thresh, J.M.; Bellotti, A.C., eds. Cassava: biology, production and utilization. CABI, Wallingford, UK.

Jones, J.W.; Hoogenboom, G.; Porter, C.H.; Boote, K.J.; Batchelor, W.D.; Hunt, L.A.; Wilkens, P.W.; Singh, U.; Gijsman, A.J.; Ritchie, J.T. 2003. The DSSAT cropping system model. European Journal of Agronomy 18: 235-265.

Kawano, K. 1990. Harvest index and evolution of major food crop cultivars in the tropics. Euphytica 46: 195-202.

Keating, B.A.; Evenson, J.P.; Fukai, S. 1982a. Environmental effects on growth and development of cassava (Manihot esculenta Crantz). II. Crop growth rate and biomass yield. Field Crops Research 5: 283-292.

Keating, B.A.; Evenson, J.P.; Fukai, S. 1982b. Environment effects on growth and development of cassava (Manihot esculenta Crantz). III. Assimilate distribution and storage organ yield. Field Crops Research 5: 293-303. 
Koutroubas, S.D.; Papakosta, D.K.; Doitsinis, A. 2009. Phenotypic variation in physiological determinants of yield in spring sown safflower under Mediterranean condition. Field Crops Research 112: 199-204.

Lahai, M.T.; George, J.B.; Ekanayake, I.J. 1999. Cassava (Manihot esculenta Crantz) growth indices, root yield and its components in upland and inland valley ecologies of Sierra Leone. Journal of Agronomy and Crop Science 182: 239-247.

Lebot, V. 2009. Tropical Root and Tuber Crops: Cassava, Sweet Potato, Yam and Aroids. CABI, Wallingford, UK.

Lenis, J.I.; Calle, F.; Jaramillo, G.; Perez, J.C.; Ceballos, H.H.; Cock, J.H. 2006. Leaf retention and cassava productivity. Field Crops Research 95: 126-134.

Phakamas, N.; Jintrawet, A.; Patanothai, A.; Sringam, P.; Hoogenboom, G. 2013. Estimation of solar radiation based on air temperature and application with the DSSAT v4.5 peanut and rice simulation models in Thailand. Agricultural and Forest Meteorology 180: 182-193.
Phuntupan, K.; Banterng, P. 2017. Physiological determinants of storage root yield in three cassava genotypes under different nitrogen supply. The Journal of Agricultural Science 155: 978992.

Ramanujam, T. 1985. Leaf density profile and efficiency in partitioning dry matter among high and low yielding cultivars of cassava (Manihot esculenta Crantz). Field Crops Research 10: 291-303.

Thailand Ministry of Agriculture and Cooperatives. 2008. Good agricultural practices for cassava. National Bureau of Agricultural Commodity and Food Standards Ministry of Agriculture and Cooperatives, Thailand.

Vilayvong, S.; Banterng, P.; Patanothai, A.; Pannangpetch, K. 2015. CSM-CERES-Rice model to determine management strategies for lowland rice production. Scientia Agricola 72: 229-236.

White, J.W.; Hoogenboom, G. 2003. Gene-based approaches to crop simulation. Agronomy Journal 95: 52-64. 